Article

\title{
Relationships among Government Funding, R\&D Model and Innovation Performance: A Study on the Chinese Textile Industry
}

\author{
Zhiying Zhang ${ }^{1,2,3}$, Hua Cheng ${ }^{1,3, *}$ and Yabin Yu ${ }^{1,4}$ \\ 1 School of Economics and Management, Zhejiang Sci-Tech University, Hangzhou 310018, China; \\ 949801@zstu.edu.cn (Z.Z.); yabinyu@cjlu.edu.cn (Y.Y.) \\ 2 School of Science, Zhejiang Sci-Tech University, Hangzhou 310018, China \\ 3 Ecological Civilization Research Center of Zhejiang Province, Zhejiang Sci-Tech University, \\ Hangzhou 310018, China \\ 4 College of Economics and Management, China Jiliang University, Hangzhou 310018, China \\ * Correspondence: chenghua@zstu.edu.cn
}

Received: 30 November 2019; Accepted: 11 January 2020; Published: 15 January 2020

\begin{abstract}
The textile industry is a traditional pillar industry of the national economy in China. The strategic goal of Chinese innovation is to upgrade and transform traditional industries and make them develop in coordination with high-tech industries, so as to realize sustainable industrial development. At the core of industrial sustainable development, the innovation of the textile industry in China has become an important issue worthy of attention. Based on resource-based theory and signal transfer theory, the relationship between government funding, $R \& D$ models and the innovation performance of the Chinese textile industry is studied. The results show that government funding has a significant, direct promoting effect on the internal $R \& D$ and science-based cooperation of enterprises. Government funding indirectly promotes market-based cooperation through internal R\&D. The promoting effect of internal $R \& D$ on innovation performance is greater than that of cooperative $R \& D$. Internal $R \& D$ and cooperative $R \& D$ have more promoting effects on $R \& D$ reserve performance than those on market performance. Government funding indirectly promotes innovation performance through the mediation of internal R\&D and science-based cooperation. The threshold effect of cooperative R\&D indicates that only when the cooperative $R \& D$ intensity exceeds the threshold can government funding foster innovation performance more effectively. The conclusions can provide theoretical guidance for the formulation of innovation policy.
\end{abstract}

Keywords: government funding; R\&D model; textile industry; innovation performance

\section{Introduction}

As the strategic form of enterprise's R\&D activities, R\&D models can be divided into internal $R \& D$ and cooperative $R \& D$, based on organizational boundaries and knowledge sources [1]. Internal $R \& D$ ability is the source of sustainable competitive advantage. However, market failure due to the externality of $R \& D$ products may lead to the lower level of $R \& D$ investment in the whole society. In order to encourage enterprises $R \& D$ investment, the government has launched various direct or indirect policy instruments [2-4]. Enterprises are the main body of innovation. The government wants to encourage enterprises to increase R\&D investment through $R \& D$ subsidies, thereby improving innovation performance. Internal R\&D is the main channel through which to enhance independent innovation ability. However, nowadays, the Chinese textile industry may face problems such as low initiative of independent innovation, lack of innovative resources and the inefficient allocation of 
resources which lead to lower innovation performance. Therefore, how to improve the initiative of independent innovation has become a concern of government and enterprises.

Innovation requires more and more cooperation between enterprises and external partners [2]. The open innovation paradigm clarified that the more diverse the channels for enterprises to obtain innovative resources, the more abundant the innovative resources available [5]. The more likely they are to carry out a variety of R\&D activities, the faster the innovation capability will be improved. Many studies emphasized the importance of external knowledge sources to enterprise innovation and believed that cooperative R\&D can effectively promote innovation performance [6], but it may also require lots of resources [7]. In recent years, China has viewed cooperative innovation as an important strategy in building an innovative country, and issued a series of policies to promote cooperative innovation. The Outline of the National Medium-and Long-Term Science and Technology Development Plan (2006-2020), issued by the State Council of China clearly proposed to encourage enterprises to carry out cooperative $R \& D$.

Much of the literature has studied the effect of government funding. Firstly, they mainly focused on the complementary and crowding-out effect of government funding on enterprise internal $R \& D[2,8]$, while the exploration of the relationship between government funding and different forms of cooperative R\&D being carried out by enterprises was limited. On the other hand, many studies focused on whether government funding significantly promotes innovation performance [9]. These research perspectives mainly focused on the input side and the output side, while there were few systematic studies that incorporated the diversified behavior side of enterprises into the framework. Because less attention has been paid to the complex linkage between government funding, internal $R \& D$, cooperative $R \& D$ and innovation performance, the internal mechanism of government funding impacting innovation performance cannot be clearly revealed.

When it comes to the body of innovation, people pay more attention to the high-tech industries. Innovation of some traditional industries with low and medium technology is often neglected. In fact, the contribution of low and medium-tech industries to the economy is great. The project "policy and innovation in low tech" (PILOT)—funded by the European Commission—studied the technological innovation of traditional industries with low and medium technology in many European countries. They found that these industries have great significance for economic development. The adjustment of economic structure does not entirely depend on emerging industries, but to a large extent depends on the continuous transformation of existing industries. Different from the radical innovation of high-tech industry, the innovation of middle and low-tech industry is incremental innovation which is mainly produced by the original recombination or transformation of various available resources. There is an interdependent, symbiotic relationship between the low-tech industry and the high-tech industry. The important contribution of traditional industries to innovation cannot be ignored.

Traditional industries played an important role in the rapid development of the Chinese economy. In China, the textile industry is a typical low-tech industry, as well as a traditional pillar industry of the national economy. The improvement of innovation behavior and efficiency is still related to employment, export, industrial transfer and international competition. According to the Fourth National Economic Census of China, R\&D expenditure in the textile industry in 2018 accounted for $3.70 \%$ of the national manufacturing industry. The R\&D expenditure from government also increases gradually. However, for a long time, most of the technology sources of textile enterprises mainly relied on the introduction of technology and imitation manufacturing. Technological innovations were ignored, resulting in low industrial concentrations, backward production equipment technology, low technological content of products, weak technological development ability, etc. All these have seriously hindered the improvement of the innovation ability of textile industry. The goal of China's innovation strategy is not to abolish the traditional industry, but to upgrade and transform the traditional industry so that it can develop in coordination with the high-tech industry. Therefore, in the context of the new normal of China's economy, it is of great significance to attach importance to the scientific and technological innovation of the textile industry. How to realize the industrial upgrade and achieve 
the sustainable development of textile industry through technological innovation have both become important issues of concerned to all sectors of society.

Based on the above, we explored the complex relationship between government funding, $R \& D$ models and the innovation performance of the Chinese textile industry. The contribution of this study lies in that firstly, the innovation behavior of enterprise is introduced into the existing research framework of the relationship between input and output which is composed of government funding and innovation performance. Enterprise innovation behavior is represented by the innovation model which includes internal R\&D and cooperative R\&D. Furthermore, enterprises can acquire advanced scientific knowledge through cooperating with universities, research institutes, etc. This type of cooperation is suitable for basic science research, which can provide the conditions for enterprise's scientific research reserve. We call this science-based cooperation (SCI). Cooperation between enterprises and organizations other than universities and research institutes can realize the complementary relationship of resources and information between organizations. All partners work hard to achieve common market goals [10-12]. This type of cooperation can be defined as market-based cooperation (MAR). Therefore, according to different partners, cooperative $R \& D$ is divided into science-based cooperation and market-based cooperation. From the perspective of process and result, innovation performance is divided into R\&D reserve performance and market performance. Based on the expanded research framework, the mechanism of government funding affecting enterprise innovation behavior and performance has been revealed. To a certain extent, our study may be able to enrich the existing research perspectives of enterprise innovation.

Secondly, further development of the innovative theory of the textile industry suitable for China's national conditions may be able to provide useful reference for the formulation and implementation of China's science and technology policy-especially the policy of promoting Chinese traditional industries innovation. At the same time, taking the textile industry as the research object can avoid the thinking stereotype that innovation is only about high-tech industry.

The rest of the paper is arranged as follows. Literature is reviewed and hypotheses are proposed in Section 2. Variables and models are introduced in Section 3. Results of empirical analysis are shown in Section 4. Conclusions are given in Section 5.

\section{Literature and Hypotheses}

\subsection{Government Funding and RED Model}

\subsubsection{Government Funding and Internal R\&D}

The resource endowment of an enterprise determines its innovation ability and willingness [13] which has an impact on its innovation strategy. To avoid the lower R\&D enthusiasm caused by the externality of R\&D activities, the government will effectively intervene in the innovation of enterprises through the mechanism of supplementing resources. As an effective supplementary resource, government subsidies can help enterprises to reduce the marginal cost and risks of innovation activities and improve profits. As a result, the externalities of R\&D activities are internalized [14], and the R\&D investment of enterprises can be significantly stimulated. At the same time, due to information asymmetry, it is difficult for enterprises to obtain external investment, which leads to more serious financial constraints [15]. Government funding can act as an intermediary for information transmission, and transmit a favorable signal to the market for subsidized enterprises. Enterprises acquire a recognized qualification and are more likely to attract bank loans and social funds, thus actively increasing R\&D investment [16,17]. A large number of studies have concluded that government funding has both a complementary and a substitution effect on R\&D investment [17-19], but the complementary effect was supported by most of the studies. 


\subsubsection{Government Funding and Cooperative R\&D}

For those projects involving complex technologies, a large amount of investment is required. Governments can increase the resource availability of enterprises through resource replenishment mechanisms. Enterprise innovation costs can be effectively reduced, which makes it more likely to adopt open innovation initiatives [2]. As a result, the number of partners will increase, and the quality of cooperation will be improved. Enterprises with more ideal partners tend to carry out more diversified cooperative $R \& D$.

Because of information asymmetry, enterprises cannot get all the information of other organizations, which increases the difficulty of searching and identifying partners. The government can act as an intermediary to help enterprises eliminate redundant information, or build an efficient technology trading market to provide venues for enterprises to find suitable partners $[17,20]$. For some start-ups or enterprises with weak innovation ability, this approach allows them to connect with potential partners with expertise or technology.

Open innovation requires a variety of complex relationships between enterprises and other organizations to overcome information barriers and contract problems [21]. There must be an appropriate institutional environment to enable all parties to cooperate in an orderly manner, so as to reduce the supervision cost of enterprise. Government can provide a variety of financial support to promote the establishment of collaborative links among organizations from the perspective of institutional guaranteein order to increase the number of open innovation activities of enterprises and make them more open. Numerous studies have argued that government funding is conducive to active cooperation between enterprises and universities, research institutions and other organizations [22-24].

A large number of intelligent manufacturing lines and factories have emerged in the textile industry recently. The level of digitalization and intellectualization has been greatly improved, and some breakthroughs have been made in key technologies. The innovation prospect of China's textile industry is the development of intelligent textile materials and products, the improvement of labor productivity and product quality, and the acceleration of the transformation and upgrading of the textile industry. However, the lack of $R \& D$ investment has seriously hindered the improvement of innovation ability. Therefore, no matter whether from the perspective of resource supplement or the perspective of risk and cost reduction, government funding will be conducive to the development of new technology innovation in the textile industry.

Thus, the following hypothesis is put forward in view of the relationship between government funding and R\&D model in Chinese textile industry.

Hypothesis 1 (H1). Government funding directly promotes internal RED and cooperative RED.

\subsubsection{Government Funding, Internal R\&D and Cooperative R\&D}

The ability of an enterprise to carry out cooperative R\&D will also be enhanced with the enhancement of internal R\&D capability. In the open innovation system, strong internal R\&D capability is conducive to successful enterprises. Enterprises must have strong R\&D capabilities in order to cooperate with other enterprises in core technology, so to find solutions to the problem of breakthrough innovation. Only with strong internal R\&D capabilities can enterprises effectively utilize external technology and knowledge, integrate them with internal resources, allocate them effectively, and promote innovation performance [25-28]. In addition, when choosing partners, enterprises attach great importance to each other's R\&D capabilities. The stronger the internal R\&D capability of enterprises, the more frequently they participate in technical cooperation $[25,29,30]$. As a result, these enterprises are more likely to become ideal partners of other organizations. Therefore, as an important factor to promote cooperative $R \& D$, internal $R \& D$ creates favorable conditions for cooperative $R \& D$. 
Because of the positive impact of internal $R \& D$ on cooperative $R \& D$, as well as the effect of government funding on internal $R \& D$, government funding can promote cooperative $R \& D$ by promoting internal R\&D. Therefore, the following assumption is put forward:

Hypothesis 2 (H2). Government funding promotes internal $R \mathcal{E} D$, and further promotes the cooperative RED.

\subsection{Government Funding and Innovation Performance}

The forms of government support for enterprises are direct subsidies, tax incentives, government-funded laboratories or advanced facilities and so on. Some of them focus on the input of enterprise innovation process (i.e., supply side) and some focus on innovation output (i.e., demand side) [31]. Government subsidies, whether in monetary or non-monetary form, can add additional innovative resources to enterprises and effectively reduce the risk and cost of R\&D. The financial constraints of enterprises can be mitigated so as to conduct a new round of R\&D investment, which is expected to increase innovation output [2,32].

As the best way for an enterprise to acquire the necessary skills and knowledge, internal R\&D is the most fundamental factor to maintain innovation ability and promote technological innovation [33]. Researchers have found that internal R\&D is positively correlated with innovation performance [34,35]. Cooperative R\&D is an effective model for enterprises to share knowledge and technology [36]. Innovation is not only the internal efforts of enterprises, but also the use of external resources to replenish the internal innovation efforts [37]. Cooperating with other organizations helps enterprises to achieve breakthrough innovation and improve the success rate of innovation [38-40].

Because different R\&D models have positive promoting effects on innovation performance, government funding can play a full role in promoting innovation performance through R\&D models. Firstly, government funding provides a supplementary resource for enterprises [3] and enables enterprises to allocate sufficient resources to engage in internal $R \& D$ or cooperative $R \& D$. The $R \& D$ investment of enterprises not only improves their own innovation performance, but also improves the innovation level of the whole society due to the technology spillover effect, so that the expectation of government funding can be realized. When the purposes of enterprises are in line with those of the government, enterprises can further attract more government funding. So, there is a virtuous circle: Government funding — R\&D investment—innovation performance-government funding-etc. Government funding reduces R\&D costs and R\&D risks by supporting R\&D activities [32], and guides enterprises to increase innovation investment. Enterprises turn government funding into R\&D funds, thus promoting the overall innovation level.

Government funding is secondly conducive to the effective allocation of $R \& D$ resources. Government funding is a supplement to the original $R \& D$ resources of enterprises while $R \& D$ investment of enterprises brings breakthroughs in the structure of $R \& D$ resources. Knowledge spillover caused by market information feedback will guide enterprises to allocate innovation resources more effectively. The cooperative R\&D of enterprises especially can fully reduce the duplicate investment and improve the efficiency of utilization. In many developed countries, the government encourages enterprises to participate in cooperation in the R\&D stage and competition in the goods production and marketing stages. Therefore, government funding policies are gradually inclined to encourage enterprises to cooperate in $R \& D$ activities. Government funding helps enterprises to seek for long-term and ideal partners in the process of cooperation. Information spillovers in the process of cooperation make enterprises have the ability to carry out cooperative $R \& D$ which is conducive to the improvement of innovation performance. Many studies showed that government support directly or indirectly promotes innovation performance through stimulating innovation activities such as internal R\&D and cooperative R\&D [41,42].

We therefore argue that government funding directly promotes enterprise innovation performance as a supplement to $R \& D$ investment. Government funding meanwhile also indirectly promotes 
innovation performance through internal $R \& D$ and cooperative $R \& D$ of enterprises. The following hypotheses are proposed for that:

Hypothesis 3 (H3). Government funding directly promotes innovation performance of enterprises.

Hypothesis 4 (H4). Government funding promotes internal RED, and then internal RED promotes innovation performance of enterprises.

Hypothesis 5 (H5). Government funding promotes cooperative RED, and then cooperative RED promotes innovation performance of enterprises.

Based on the resource-based theory, as an effective resource supplement, government funding can help enterprises reduce the marginal cost of innovation activities, share the risk of innovation activities, improve the enterprise income, and internalize the R\&D externality [14]. From the perspective of signal transmission, as an intermediary of information transmission, government funding has delivered a good signal to the market that the funded enterprises are recognized [16,17]. All of these are conducive to stimulating internal R\&D. Internal R\&D capability is the key to improving enterprise resource integration capability [43], and also the decisive factor in seeking ideal partners and participating in effective cooperative innovation. The role of the open innovation model in promoting innovation performance has been recognized by many scholars. Enterprises with different resources cooperate and conduct R\&D activities based on common innovation goals. The synergetic effect of innovation resources can be brought into full play so that technological breakthroughs will be achieved [29].

Based on this, considering the relationship between internal R\&D and cooperative R\&D mentioned in $\mathrm{H} 2$, we assume that government funding promotes innovation performance through internal R\&D and then the cooperative $R \& D$ of enterprises. The following hypothesis is proposed:

Hypothesis 6 (H6). Government funding promotes internal RED, internal RED promotes cooperative RED, and then cooperative RED promotes innovation performance of enterprises.

Figure 1 is the theoretical model of the relationship between government funding, R\&D model and innovation performance.

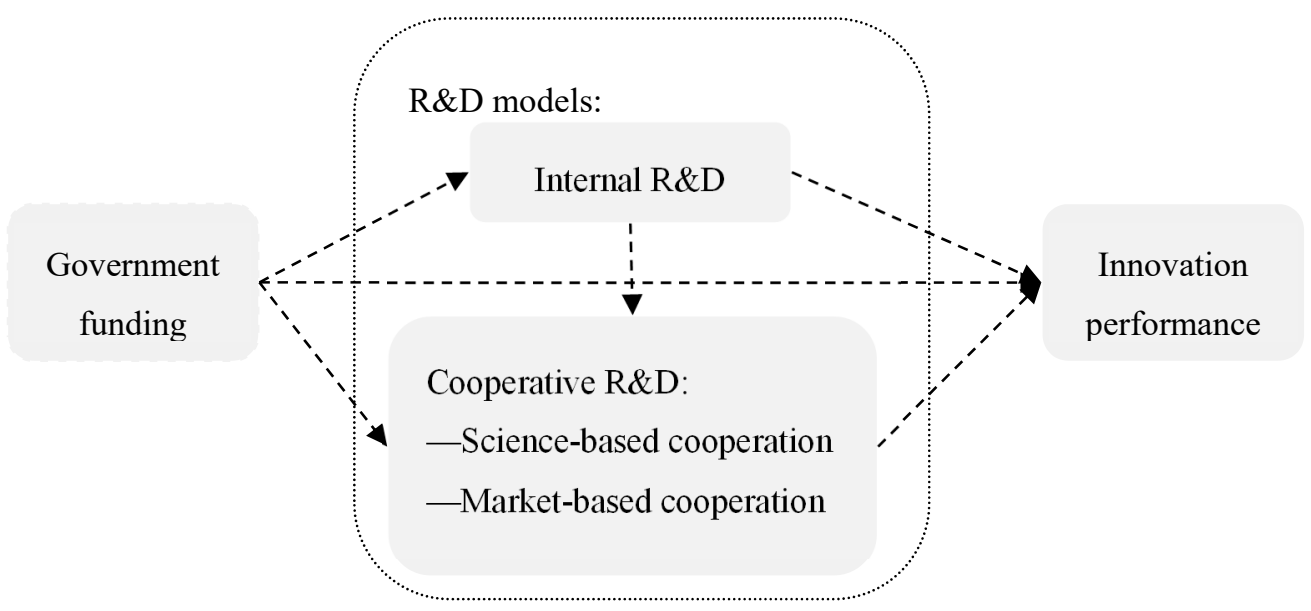

Figure 1. Theoretical model of the relationship between government funding, R\&D model and innovation performance. 


\section{Variables and Models}

\subsection{Data and Variables}

The research object of this study is Chinese textile industry. The industry level data analyzed are from the Statistical Yearbook of Scientific and Technological Activities of Chinese Industrial Enterprise from 2010 to 2016. Four sub-industries related to textile materials are selected, namely the textile industry, textile and apparel industry, fur, feather and its products manufacturing industry, and the chemical fiber manufacturing industry. Each sub-industry is divided into three sub-industries according to the size of the enterprise; namely, the sub-industry composed of large, medium and small industrial enterprises. The data units in the yearbook are based on large, medium, and small sub-industries. Accordingly, 84 observations based on industry level are obtained. Variables are set as follows:

\section{(1) Dependent variables}

Innovation performance is the efficiency of enterprise innovation process, the results of output and its contribution to business results. New products and patents are used more frequently to measure innovation performance in existing research [7,44]. New products sales revenue reflects the value created in the process of manufacturing. The number of patents reflects the inventive or innovative performance of enterprises in new technologies, processes and products. Learning from the existing literature, we argue that innovation performance should reflect both output and process performance [45-47]. So, market performance (NEW) and R\&D reserve performance (PAT) expressed by new products sales revenue and the number of patent applications are used in our study.

\section{(2) Mediate variables}

Based on organizational boundaries and knowledge sources, the R\&D model is divided into internal $R \& D$ and cooperative $R \& D$. Internal $R \& D(R D)$ is innovative activity within organizational boundaries or vertical integration of technological innovation departments [48]. The sources of the $R \& D$ funds of enterprises' internal expenditure include government funds, enterprise funds and other funds. Among them, enterprise funds reflect the extent of enterprises' efforts in internal R\&D. Internal R\&D of this paper is expressed by the funds from enterprises in the R\&D funds of enterprises' internal expenditure.

Cooperative R\&D is an innovative model for enterprises to cooperate with other organizations. The form and benefit of cooperation will be different due to the characteristics of partners. Enterprises can acquire advanced scientific knowledge through cooperation between enterprises and universities, research institutes, etc. This type of cooperation is suitable for basic science research, which can provide conditions for the scientific research reserves of enterprises. We call this science-based cooperation (SCI). Cooperation between enterprises and organizations other than universities and research institutes can realize the complementary relationship of resources and information between organizations. All partners work hard to achieve common market goals [10-12]. This type of cooperation can be defined as market-based cooperation (MAR). Science-based cooperation is expressed by the funds given to universities and research institutes in the R\&D funds of enterprise external expenditure. Market-based cooperation is expressed by the funds given to other organizations in the R\&D funds of enterprise external expenditure, respectively.

(3) Independent variable

Government funding (GOV) is the main explanatory variable. Government funding mainly includes direct subsidies and tax incentives (including direct and indirect tax incentives). This paper mainly focuses on direct subsidies. Direct subsidies mean that government directly provides research funds, government loans, government discounts and government guarantees to enterprises, etc. In this paper, the funds from government in the R\&D funds of enterprises internal expenditure are used as a proxy indicator for the government funding. 
(4) Control variables

Enterprise scale (SCAL) is an important indicator that affects the innovation performance. Enterprises with different sizes will have different R\&D innovation strategies and ways of combining and utilizing innovative resources [49]. In this paper, the enterprise scale is measured by the ratio of the main business income of an industry to the number of enterprises in the industry. Year dummy (YEAR) is needed in this study. 2011 is the boundary point of the 11th and 12th Five-Year Plan of China's textile industry. During different Five-Year planning periods, the national innovation policy and the development environment faced by enterprises will be different. Thus, we set the YEAR as 1 after 2011 and 0 otherwise.

The main variables and measurements are shown in Table 1.

Table 1. Main variables and measurements.

\begin{tabular}{|c|c|c|c|}
\hline \multicolumn{2}{|c|}{ Variables } & \multirow{2}{*}{$\begin{array}{c}\text { Symbol } \\
\text { NEW } \\
\text { PAT }\end{array}$} & \multirow{2}{*}{\begin{tabular}{l}
\multicolumn{1}{c}{ Measure } \\
New products sales revenue \\
Number of patent applications
\end{tabular}} \\
\hline $\begin{array}{l}\text { Innovation } \\
\text { performance }\end{array}$ & $\begin{array}{l}\text { Market performance } \\
\text { R\&D reserve performance }\end{array}$ & & \\
\hline \multirow{3}{*}{ R\&D model } & Internal R\&D & RD & $\begin{array}{l}\text { Funds from enterprises in the R\&D funds } \\
\text { of enterprises internal expenditure }\end{array}$ \\
\hline & Science-based cooperation & SCI & $\begin{array}{l}\text { Funds given to universities and research } \\
\text { institutes in the R\&D funds of enterprise } \\
\text { external expenditure }\end{array}$ \\
\hline & Market-based cooperation & MAR & $\begin{array}{l}\text { Funds given to other organizations in the } \\
\text { R\&D funds of enterprise external } \\
\text { expenditure }\end{array}$ \\
\hline \multicolumn{2}{|c|}{ Government funding } & GOV & $\begin{array}{l}\text { Funds from government in the R\&D funds } \\
\text { of enterprises internal expenditure }\end{array}$ \\
\hline \multicolumn{2}{|c|}{ Enterprise scale } & SCAL & $\begin{array}{l}\text { Ratio of the main business income of an } \\
\text { industry to the number of enterprises in } \\
\text { the industry }\end{array}$ \\
\hline \multicolumn{2}{|r|}{ Year } & YEAR & 1 if Year $>2011,0$ otherwise \\
\hline
\end{tabular}

\subsection{Models}

In order to test the relationship between government funding, the R\&D model and the innovation performance of textile industry, the following models ((1)-(9)) are established by introducing independent variables step by step.

$$
\begin{gathered}
\ln R D_{i t}=\alpha_{0}+\alpha_{1} \ln G O V_{i t}+\beta_{1} \ln S C A L_{i t}+\beta_{2} Y E A R_{i t}+\varepsilon_{i t} \\
\ln C O \_R D_{i t}=\alpha_{0}+\alpha_{1} \ln G O V_{i t}+\beta_{1} \ln S C A L_{i t}+\beta_{2} Y E A R_{i t}+\varepsilon_{i t} \\
\ln C O \_R D_{i t}=\alpha_{0}+\alpha_{1} \ln G O V_{i t}+\alpha_{2} \ln R D_{i t}+\beta_{1} \ln S C A L_{i t}+\beta_{2} Y E A R_{i t}+\varepsilon_{i t} \\
\ln I N N O V_{i t}=\alpha_{0}+\alpha_{1} \ln G O V_{i t}+\beta_{1} \ln S C A L_{i t}+\beta_{2} Y E A R_{i t}+\varepsilon_{i t} \\
\ln I N N O V_{i t}=\alpha_{0}+\alpha_{1} \ln G O V_{i t}+\alpha_{2} \ln R D_{i t}+\beta_{1} \ln S C A L_{i t}+\beta_{2} Y E A R_{i t}+\varepsilon_{i t} \\
\ln I N N O V_{i t}=\alpha_{0}+\alpha_{1} \ln G O V_{i t}+\alpha_{2} \ln S C I_{i t}+\beta_{1} \ln S C A L_{i t}+\beta_{2} Y E A R_{i t}+\varepsilon_{i t} \\
\ln I N N O V_{i t}=\alpha_{0}+\alpha_{1} \ln G O V_{i t}+\alpha_{2} \ln M A R_{i t}+\beta_{1} \ln S C A L_{i t}+\beta_{2} Y E A R_{i t}+\varepsilon_{i t} \\
\ln I N N O V_{i t}=\alpha_{0}+\alpha_{1} \ln G O V_{i t}+\alpha_{2} \ln R D_{i t}+\alpha_{3} \ln S C I_{i t}+\beta_{1} \ln S C A L_{i t}+\beta_{2} Y E A R_{i t}+\varepsilon_{i t} \\
\ln I N N O V_{i t}=\alpha_{0}+\alpha_{1} \ln G O V_{i t}+\alpha_{2} \ln R D_{i t}+\alpha_{3} \ln M A R_{i t}+\beta_{1} \ln S C A L_{i t}+\beta_{2} Y E A R_{i t}+\varepsilon_{i t}
\end{gathered}
$$

In models (1)-(9), CO_RD represents SCI and MAR. INNOV represents NEW and PAT. $\alpha_{0}$ is constant, $\alpha_{1}, \alpha_{2}, \alpha_{3}, \alpha_{4}, \beta_{1}$ and $\beta_{2}$ are the regression coefficients, $i$ is industry, $t$ is time, $\varepsilon_{i t}$ is random errors. 
The models will be used to test the effect of government shown in Figure 2, which has the same concept as Figure 1. The letters on the line represent the direct effect of the latter variables on the former variables. The effect of GOV is as follows [50,51]:

(I) GOV-RD-SCI/MAR. Models (1), (2) and (3) are used to test the mediation effect of RD in the process of GOV promoting SCI/MAR. The mediation effect is the product of $a$ and $b$ (i.e., $a b$ ).

(II) GOV-RD-PAT/MAR. Models (1), (4) and (5) are to test the mediation effect of RD in the process of GOV promoting PAT/NEW. The mediation effect is the product of $a$ and $f$ (i.e., af).

(III) GOV-SCI/MAR-PAT/NEW. Models (2), (4), (6) and (7) are used to test the mediation effect of $\mathrm{SCI} / \mathrm{MAR}$ in the process of GOV promoting NEW/PAT. The mediation effect is the product of $e$ and $c$ (i.e., $e c$ ).

(IV) GOV-RD-SCI/MAR-PAT/NEW. Models (1), (3), (4), (8) and (9) are used to test the multiple mediation effect of RD and SCI/MAR in the process of GOV promoting PAT/NEW. The total mediation effect can be obtained by multiplying the coefficients on the same chain and then summing the products (i.e., $a b c+a f+e c$ )

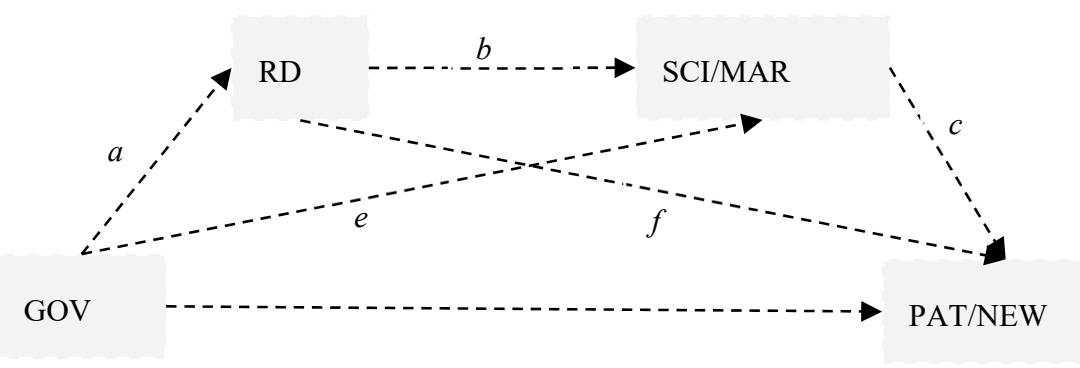

Figure 2. Path graph of the relationship between government funding (GOV), R\&D model (Internal R\&D (RD), Science-based cooperation (SCI) and Market-based cooperation (MAR)) and innovation performance (Market performance (NEW) and R\&D reserve performance (PAT)).

Considering that the effect of government funding on innovation performance varies with the intensity of cooperative $R \& D$, the interaction items of government funding and cooperative $R \& D$ are introduced to verify the threshold effect of cooperative R\&D. Let's consider an equation with interaction term: $\mathrm{y}=\mathrm{a}+\mathrm{b} x_{1}+c x_{1} x_{2}$. The derivative of $\mathrm{y}$ on $x_{1}$ is $\frac{d y}{d x_{1}}=b+c x_{2}$, which is the variable rate of $\mathrm{y}$ caused by the change of $x_{1}$. Let $\frac{d y}{d x_{1}}=b+c x_{2}=0$, then $x_{2}=-\frac{b}{c}$ is the point where the derivative equals zero. There are two situations. Firstly, when $x_{2}<-\frac{b}{c}, \frac{d y}{d x_{1}}<0$, y decreases with the increasing of $x_{1}$; Secondly, when $x_{2}>-\frac{b}{c}, \frac{d y}{d x_{1}}>0$, y increases with the increasing of $x_{1}$. Accordingly, we build models (10) and (11) to analyze the threshold effect of cooperative R\&D.

$$
\begin{gathered}
\ln N E W_{i t}=\alpha_{0}+\alpha_{1} \ln G O V_{i t}+\alpha_{2} \ln R D_{i t}+\alpha_{3} \ln G O V_{i t} \cdot \ln S C I_{i t} \\
+\beta_{1} \ln S C A L_{i t}+\beta_{2} Y E A R_{i t}+\varepsilon_{i t}
\end{gathered}
$$

where, $\alpha_{0}$ is constant, $\alpha_{1}, \alpha_{2}, \alpha_{3}, \beta_{1}$ and $\beta_{2}$ are the regression coefficients, $i$ is industry, $t$ is time, $\varepsilon_{i t}$ is random errors.

\section{Empirical Results}

The results of the descriptive statistical analysis of the main variables are shown in Table 2. The results of OLS regression are shown in Tables 3-5. The results also show the diagnostic parameters of each model. 
Table 2. Descriptive statistical analysis of main variables.

\begin{tabular}{ccccc}
\hline & Min & Max & Mean & Std. \\
\hline NEW & 12.724 & 17.096 & 15.054 & 0.915 \\
PAT & 5.628 & 9.044 & 7.261 & 0.875 \\
RD & 9.766 & 13.680 & 11.976 & 0.900 \\
SCI & 5.235 & 9.726 & 7.827 & 1.041 \\
MAR & 2.848 & 8.833 & 6.296 & 1.493 \\
GOV & 5.485 & 9.586 & 7.795 & 0.974 \\
SCAL & 8.791 & 13.139 & 10.738 & 1.367 \\
YEAR & 0 & 1 & 0.571 & 0.497 \\
\hline
\end{tabular}

Note: All variables are processed by natural logarithm and all data are converted to comparable price based on 2009.

Table 3. Relationship between government funding, the R\&D model and innovation performance.

\begin{tabular}{|c|c|c|c|c|c|c|c|c|c|}
\hline Variable & Model 1 & Model 2 & Model 3 & Model 4 & Model 5 & Model 6 & Model 7 & Model 8 & Model 9 \\
\hline $\begin{array}{l}\text { Dependent } \\
\text { variable }\end{array}$ & GOV & $\mathrm{RD}$ & $\mathrm{SCI}$ & MAR & $\mathrm{SCI}$ & MAR & NEW & NEW & NEW \\
\hline GOV & & $0.722 * * *$ & $0.709^{* * *}$ & $0.923^{* * *}$ & 0.021 * & 0.137 & $0.626^{* * *}$ & -0.035 & $0.419^{* * *}$ \\
\hline $\mathrm{RD}$ & $1.107^{* * *}$ & & & & $0.953^{* * *}$ & $1.089^{* * *}$ & & 0.915 *** & \\
\hline $\mathrm{SCI}$ & 0.002 & & & & & & & & $0.292 * * *$ \\
\hline MAR & 0.019 & & & & & & & & \\
\hline Constant & $-3.809 * * *$ & $4.307^{* * * *}$ & 0.071 & $-3.228 * *$ & $-4.034 * * *$ & $-7.92 * * * *$ & $6.925 * * *$ & $2.984 * * *$ & $6.904^{* * *}$ \\
\hline SCAL & -0.146 & $0.167^{* * *}$ & $0.227^{* * *}$ & $0.204^{* *}$ & 0.067 & 0.022 & $0.287^{* * *}$ & 0.133 *** & $0.220^{* * *}$ \\
\hline YEAR & -0.351 & $0.389^{* * *}$ & -0.320 ** & 0.215 & $-0.691 * * *$ & -0.208 & $0.278^{* * *}$ & -0.078 & $0.371^{* * *}$ \\
\hline $\begin{array}{l}\text { Adjusted } \\
\text { R-square }\end{array}$ & 0.833 & 0.879 & 0.634 & 0.461 & 0.712 & 0.506 & 0.834 & 0.931 & 0.873 \\
\hline F-statistic & 75.887 & 181.980 & 44.261 & 42.954 & 47.380 & 43.499 & 109.913 & 143.662 & 74.554 \\
\hline $\begin{array}{c}\text { Prob } \\
\text { (F-statistic) }\end{array}$ & 0.000 & 0.000 & 0.000 & 0.000 & 0.000 & 0.000 & 0.000 & 0.000 & 0.000 \\
\hline Max VIF & 4.756 & 1.169 & 1.169 & 1.169 & 8.583 & 8.583 & 1.169 & 8.583 & 2.844 \\
\hline Sobel test & & & & & $4.394^{* * *}$ & $2.668^{* * *}$ & & $8.673^{* * *}$ & $3.428^{* * *}$ \\
\hline $\begin{array}{c}\text { Mediate effect } \\
\text { BootCI }^{\mathrm{a}}\end{array}$ & & & & & $\begin{array}{c}0.688 \\
(0.378,1.072)\end{array}$ & $\begin{array}{c}0.786 \\
(0.258,0.964)\end{array}$ & & $\begin{array}{c}0.661 \\
(0.526,0.823)\end{array}$ & $\begin{array}{c}0.207 \\
(0.109,0.309)\end{array}$ \\
\hline
\end{tabular}

*: Significant at $p=0.1{ }^{* *}$ : Significant at $p=0.05 .{ }^{* * *}$ : Significant at $p=0.01 .{ }^{\text {a }}$ : Number of bootstrap samples for mediate effect confidence intervals is 5000 . Level of confidence is $95 \%$. The interval excluding 0 indicates that the mediation effect is significant; otherwise the mediation effect is not significant. The same below.

Table 4. Relationship between government funding, the R\&D model and innovation performance (continues).

\begin{tabular}{|c|c|c|c|c|c|c|c|c|c|}
\hline Variable & Model 10 & Model 11 & Model 12 & Model 13 & Model 14 & Model 15 & Model 16 & Model 17 & Model 18 \\
\hline $\begin{array}{l}\text { Dependent } \\
\text { variable }\end{array}$ & NEW & NEW & NEW & PAT & PAT & PAT & PAT & PAT & РАТ \\
\hline GOV & $0.498^{* * *}$ & -0.037 & -0.043 & $0.623^{* * *}$ & $-0.285^{* *}$ & $0.289^{* * *}$ & $0.410 * * *$ & -0.290 & -0.303 \\
\hline $\mathrm{RD}$ & & $0.821^{* * *}$ & $0.847^{* * *}$ & & $1.258^{* * *}$ & & & $1.045^{* * *}$ & $1.116^{* * * *}$ \\
\hline SCI & & 0.099 & & & & $0.470^{* * *}$ & & $0.224^{* *}$ & \\
\hline MAR & $0.138 * * *$ & & $0.063^{* *}$ & & & & $0.230^{* * *}$ & & $0.131^{* * *}$ \\
\hline Constant & $7.372^{* * *}$ & $3.381^{* * *}$ & $3.482 * * *$ & $4.906^{* * *}$ & -0.512 & $4.872^{* * *}$ & $5.648^{* * *}$ & 0.391 & 0.523 \\
\hline SCAL & $0.258^{* * *}$ & $0.127^{* * *}$ & $0.132 * * *$ & $-0.254^{* * *}$ & $-0.465^{* * *}$ & $-0.361^{* * *}$ & $-0.310^{* * *}$ & $-0.480^{* * *}$ & $-0.467^{* * *}$ \\
\hline YEAR & $0.247^{* * *}$ & -0.011 & -0.066 & $0.361^{* *}$ & -0.128 & $0.512 * * *$ & $0.312 * *$ & 0.027 & -0.101 \\
\hline $\begin{array}{l}\text { Adjusted } \\
\text { R-square }\end{array}$ & 0.859 & 0.934 & 0.935 & 0.565 & 0.764 & 0.675 & 0.643 & 0.782 & 0.786 \\
\hline F-statistic & 42.954 & 100.529 & 142.935 & 53.184 & 94.323 & 51.606 & 49.326 & 86.671 & 74.567 \\
\hline $\begin{array}{c}\text { Prob } \\
\text { (F-statistic) }\end{array}$ & 0.000 & 0.000 & 0.000 & 0.000 & 0.000 & 0.000 & 0.000 & 0.000 & 0.000 \\
\hline Max VIF & 1.932 & 10.072 & 9.505 & 1.169 & 8.583 & 2.844 & 1.932 & 10.072 & 9.505 \\
\hline Sobel test Z & 3.595 *** & $\begin{array}{l}Z_{\mathrm{RD}}: 7.347^{* * *} \\
\mathrm{Z}_{\mathrm{SCI}}: 2.188^{* *}\end{array}$ & $\begin{array}{l}Z_{\mathrm{RD}}: 7.347^{* * *} \\
\mathrm{Z}_{\mathrm{MAR}}: 2.188^{* *}\end{array}$ & & $6.345^{* * *}$ & $4.340^{* * *}$ & $3.383^{* * *}$ & $\begin{array}{l}Z_{\mathrm{RD}}: 4.823 * * * \\
\mathrm{Z}_{\mathrm{SCI}}: 2.411 * *\end{array}$ & $\begin{array}{l}Z_{\mathrm{RD}}: 5.451 * * * \\
\mathrm{Z}_{\mathrm{MAR}}: 2.591 * *\end{array}$ \\
\hline $\begin{array}{c}\text { Total Mediate } \\
\text { effect } \\
\text { BootCI } \\
\end{array}$ & $\begin{array}{c}0.128 \\
(0.067,0.205)\end{array}$ & $\begin{array}{c}0.663 \\
(0.535,0.819)\end{array}$ & $\begin{array}{c}0.669 \\
(0.547,0.825)\end{array}$ & & $\begin{array}{c}0.908 \\
(0.660,1.178)\end{array}$ & $\begin{array}{c}0.333 \\
(0.211,0.476)\end{array}$ & $\begin{array}{c}0.212 \\
(0.102,0.342)\end{array}$ & $\begin{array}{c}0.913 \\
(0.684,1.163)\end{array}$ & $\begin{array}{c}0.926 \\
(0.675,1.182)\end{array}$ \\
\hline Mediate effect I & & $\begin{array}{c}0.593 \\
(0.428,0.793) \\
\end{array}$ & $\begin{array}{c}0.611 \\
(0.464,0.799) \\
\end{array}$ & & & & & $\begin{array}{c}0.754 \\
(0.504,1.071) \\
\end{array}$ & $\begin{array}{c}0.805 \\
(0.533,1.072) \\
\end{array}$ \\
\hline Mediate effect II & & $\begin{array}{c}0.068 \\
(-0.013,0.189) \\
\end{array}$ & $\begin{array}{c}0.049 \\
(0.011,0.121) \\
\end{array}$ & & & & & $\begin{array}{c}0.154 \\
(0.044,0.343) \\
\end{array}$ & $\begin{array}{c}0.103 \\
(0.018,0.257)\end{array}$ \\
\hline $\begin{array}{c}\text { Mediate effect } \\
\text { III }\end{array}$ & & $\begin{array}{c}0.002 \\
(-0.038,0.047)\end{array}$ & $\begin{array}{c}0.009 \\
(-0.026,0.058)\end{array}$ & & & & & $\begin{array}{c}0.005 \\
(-0.085,0.094)\end{array}$ & $\begin{array}{c}0.018 \\
(-0.068,0.090)\end{array}$ \\
\hline
\end{tabular}


Table 5. The threshold effect of cooperative $R \& D^{b}$.

\begin{tabular}{ccccc}
\hline Variable & Model 19 & Model 20 & Model 21 & Model 22 \\
\hline Dependent variable & NEW & NEW & PAT & PAT \\
\hline GOV & $-0.217^{* *}$ & -0.119 & $-0.605^{* * *}$ & $-0.465^{* * *}$ \\
RD & $0.752^{* * *}$ & $0.818^{* * *}$ & $1.057^{* * *}$ & $1.145^{* * *}$ \\
GOV ${ }^{*}$ SCI & $0.331^{* *}$ & & $0.529^{* * *}$ & \\
GOV MAR & & $0.182^{* * *}$ & & $0.328^{* * *}$ \\
SCAL & $0.185^{* * *}$ & $0.199^{* * *}$ & $-0.749^{* * *}$ & $-0.727^{* * *}$ \\
YEAR & 0.016 & -0.033 & 0.021 & -0.055 \\
Adjusted R-square & 0.940 & 0.939 & 0.785 & 0.789 \\
F-statistic & 235.357 & 231.240 & 55.909 & 57.075 \\
Prob (F-statistic) & 0.000 & 0.000 & 0.000 & 0.000 \\
Max VIF & 9.184 & 9.422 & 9.184 & 9.422 \\
Threshold value & 0.656 & 0.654 & 1.144 & 1.418 \\
\hline
\end{tabular}

b. For comparison, the regression coefficients in Table 5 are standardized coefficient.

(1) Model 1 is the regression of GOV on firm characteristics. The coefficient of RD is significantly positive. The coefficient of SCI, MAR, SCAL and YEAR are insignificant. It can be inferred that the government has a preference to provide funding for enterprises with strong R\&D strength. As far as the sample data in this paper are concerned, it is not clear whether large enterprises are more attractive to government funding. Similarly, there is no evidence that the government has a preference for providing financial support to enterprises with different intensity of external cooperation R\&D or in different years.

Model 2 to Model 4 show that government funding promotes internal R\&D and cooperative RD significantly. The coefficients of GOV on RD, SCI and MAR are 0.722, 0.709 and 0.923, respectively. All of them are significant at 0.01 . In the process of stimulating innovation activities, a $1 \%$ increase in GOV will result in a $0.722 \%, 0.709 \%$ and $0.923 \%$ increase in RD, SCI and MAR, respectively.

(2) Model 5 and Model 6 show the significant mediating effect of internal R\&D in the process of government funding promoting cooperative R\&D. In Model 5, the coefficients of GOV and RD are 0.021 and 0.953 , respectively. They are significant at 0.05 and 0.01 . Given that 0.021 is less than 0.709 and Sobel test is significant at 0.01 , internal R\&D plays a significant partial mediating role in the process of government funding promoting science-based cooperation. The mediation effect of RD is 0.688 (i.e., $0.722 \times 0.953$ ).

The coefficient of GOV is not significant in Model 6. The coefficient of RD is 1.089 and significant. Sobel test is significant at 0.01 . Internal $R \& D$ plays a significant completely mediating role in the process of government funding promoting market-based cooperation. The role of government funding in promoting market-based cooperation is realized entirely through internal $R \& D$. The mediation effect of $\mathrm{RD}$ is 0.786 (i.e., $0.722 \times 1.089$ ).

Therefore, Hypothesis 1 is partially supported. Hypothesis 2 is supported.

(3) Model 7-Model 12 examine the direct and indirect effect of government funding and R\&D model on market performance. In Model 7, the coefficient of GOV is 0.626 and significant at 0.01 . The coefficient of GOV in Model 8 is not significant, while the coefficient of RD (0.915) is significant and positive. Sobel test is significant at 0.01 in Model 8. Internal R\&D plays a significant completely mediating role in the process of government funding promoting market performance. The promoting effect of government funding on market performance is realized entirely through internal R\&D. The mediation effect of RD is 0.661 (i.e., $0.722 \times 0.915$ ).

In Model 9 and Model 10, the coefficients of GOV (0.419 and 0.498) are significant but less than 0.626. The coefficients of SCI and MAR (0.292 and 0.138) are all significant and positive. Without thinking about $\mathrm{RD}$, cooperative $\mathrm{R} \& \mathrm{D}$ plays partial mediating role in the process of government funding promoting market performance. The mediating effect of SCI is 0.207 (i.e., $0.709 \times 0.292$ ) and the 
mediating effect of MAR is 0.128 (i.e., $0.923 \times 0.138$ ). The mediation effect of science-based cooperation is greater than that of market-based cooperation.

Model 11 and Model 12 show the direct effect of government funding and R\&D model on market performance. The coefficient of GOV is not significant, which is consistent with the previous analysis. The promoting effect of government funding on market performance needs to be achieved through internal R\&D and cooperative R\&D. That is, GOV promotes RD, RD promotes SCI/MAR and then SCI/MAR promote NEW. The total mediation effect can be obtained by multiplying the coefficients on the same chain and then summing the products. The total mediation effect in Model 11 is 0.663 , which is the sum of 0.593 (i.e., $0.722 \times 0.821$ ), 0.068 (i.e., $0.722 \times 0.953 \times 0.099$ ) and 0.002 (i.e., $0.021 \times 0.099$ ). Similarly, the total mediation effect in Model 12 is 0.669 , which is the sum of 0.611 (i.e., $0.722 \times 0.847$ ), 0.049 (i.e., $0.722 \times 1.089 \times 0.063$ ) and 0.009 (i.e., $0.137 \times 0.063$ ). Although the mediation effect of some chains is not significant, but the total mediation effect is significant.

Comparing the coefficients of R\&D models, we can see that internal $R \& D$ has the greatest promoting effect on market performance (0.821 in Model 11 and 0.847 in Model 12), followed by market-based cooperation (0.063). The promoting effect of science-based cooperation is not significant.

(4) Model 13-Model 18 show the direct and indirect effects of government funding and R\&D models on R\&D reserve performance. In Model 13, the coefficient of GOV is 0.623 and significant at 0.01. The coefficient of GOV in Model 14 is negative, while the coefficient of RD is significant and positive (1.258). By comparing the coefficients of Models 13 and 14, we can see that internal R\&D plays significant mediating role in the process of government funding promoting R\&D reserve performances. The mediation effect of RD is 0.908 (i.e., $0.722 \times 1.258$ ). Similarly, the results of Model 15 and Model 16 indicate that cooperative $R \& D$ plays a partial mediating role in the process of government funding promoting R\&D reserve performance. The mediation effect of $\mathrm{SCI}$ is 0.333 (i.e., $0.709 \times 0.470$ ) and the mediation effect of MAR is 0.212 (i.e., $0.923 \times 0.230$ ).

Model 17 and Model 18 show the direct effect of government funding and R\&D models on R\&D reserve performance. The coefficient of GOV is not significant. Government funding has no significant direct effect on R\&D reserve performance. The negative regression coefficients of GOV in these models also indicate a significant mediating effect of $R \& D$ models. The promoting effect of government funding on R\&D reserve performance needs to be achieved through internal R\&D and cooperative R\&D. That is, GOV promotes RD, RD promotes SCI/MAR and then SCI/MAR promotes PAT. The total mediation effect can be obtained by multiplying the coefficients on the same chain and then summing the products. The total mediation effect in Model 17 is 0.913 which is the sum of 0.754 (i.e., $0.722 \times$ 1.045), 0.154 (i.e., $0.722 \times 0.953 \times 0.224$ ) and 0.005 (i.e., $0.021 \times 0.224$ ). Similarly, the total mediation effect in Model 18 is 0.926 which is the sum of 0.805 (i.e., $0.722 \times 1.116$ ), 0.103 (i.e., $0.722 \times 1.089 \times 0.131$ ) and 0.018 (i.e., $0.137 \times 0.131$ ). Although the mediation effect of some chains is not significant, but the total mediation effect is significant.

Therefore, Hypothesis 3 is unsupported. Hypotheses 4-6 are supported.

It can be seen that the coefficients of internal R\&D and cooperative R\&D in Model 11 and Model 12 are all smaller than those in Model 17 and Model 18. The effects of R\&D investment on R\&D reserve performance are greater than that on market performance.

In conclusion, neither market performance nor R\&D reserve performance can be directly promoted by government funding. Government funding promotes innovation performance through internal $\mathrm{R} \& \mathrm{D}$ and cooperative R\&D. Government funding also has no direct effect on market-based cooperation, but indirectly promotes it through internal R\&D. Internal R\&D is an important promotion factor for innovation performance. The promoting effect of science-based cooperation on innovation performance is greater than that of market-based cooperation. The effects of cooperative $R \& D$ on $R \& D$ reserve performance are greater than that on market performance.

Based on above, a revised path graph of the relationship between government funding, R\&D model and innovation performance is shown in Figure 3 (Panel (a) and (b)). Insignificant coefficients and the control variables do not appear in the graph for brevity. 


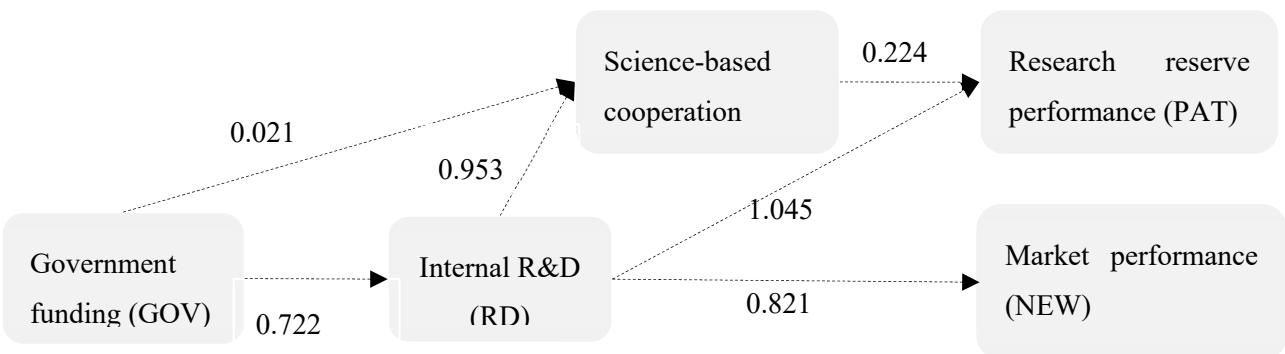

(a)

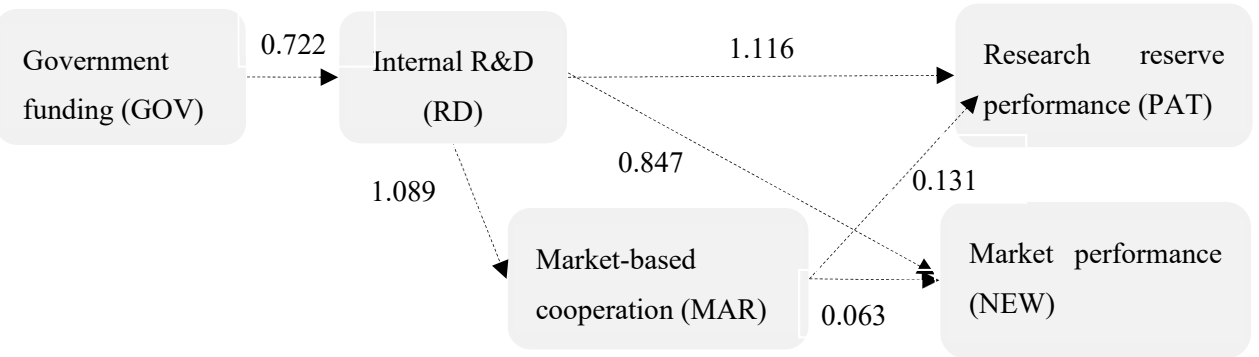

(b)

Figure 3. Revised path graph of the relationship between government funding, R\&D model and innovation performance. Panel (a) is the path of GOV-RD-SCI-PAT/NEW. Panel (b) is the path of GOV-RD-MAR-PAT/NEW.

The path graph shows that the indirect effects of government funding on innovation performance are mainly as follows: Firstly, government funding promotes internal R\&D, which in turn promotes innovation performance; Secondly, government funding promotes internal $R \& D$, internal $R \& D$ promotes cooperative R\&D, and then cooperative R\&D promotes innovation performance; Thirdly, government funding promotes science-based cooperation, and science-based cooperation promotes innovation performance.

Comparing the coefficients in each path, we can find that some of the coefficients of the latter links are smaller than those of the former's. For example, in the path of GOV-SCI-PAT, there is 0.021 $<0.224$. On the contrary, some of the coefficients of the latter links are greater than those of the former. For example, in the path of GOV-RD-MAR-PAT, there is $1.089>0.063$. It can be seen that the leverage effect of government funding through different R\&D models is different. So, in the process of government funding promoting innovation performance through cooperative $R \& D$, what does the degree of cooperative R\&D need to be so that the leverage effect of government funding can be brought into play? We analyze whether cooperative R\&D has a critical value which makes the effect of government funding on innovation performance vary from low to high. The results are shown in Model 19-Model 22.

The coefficient of GOV in regression equation of Model 19 is $-0.217+0.331^{*}$ SCI. Let $-0.217+$ $0.331 * \mathrm{SCI}=0$, we get $\mathrm{SCI}=0.656$. When $\mathrm{SCI}$ is lower than 0.656 , government funding has a negative impact on market performance. Only when SCI exceeds 0.656 will government funding have a positive impact on market performance. Similarly, the threshold value of MAR (0.654) can be calculated from Model 20. Only when MAR exceeds 0.654 , can government funding have a positive impact on market performance. The threshold value of SCI (1.144) and MAR (1.418) in Models 21 and 22 also indicate that there are threshold effects of cooperative R\&D. The threshold values in Models 21 and 22 are larger than those in Models 19 and 20, which indicate that in the process of government funding promoting market performance through the intermediary role of cooperative $R \& D$, the needed intensity of cooperative $R \& D$ is lower than that in the process of government funding promoting R\&D reserve performance.

In addition, we compare the standardized values of the original data with the threshold values in Model 19-22 and draw the scatter diagram of the sample in Figure 4 (panel a and b). It can be 
seen that in the existing sample, the SCI and MAR of most cases are lower than the threshold values. These results seem to infer that the cooperation R\&D of China's textile industry is still in the stage of low-intensity cooperation. The lower interaction and cooperation mean that the leverage effect of government funding to promote innovation performance through cooperative research R\&D cannot be fully exerted.

a

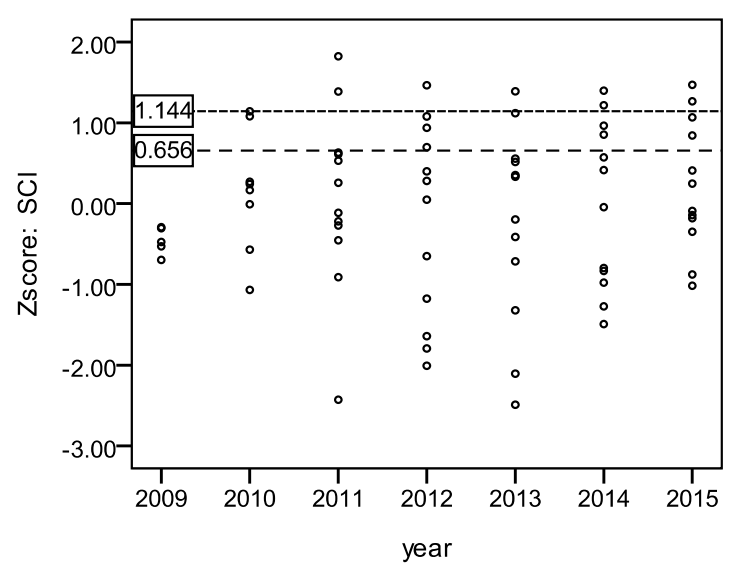

b

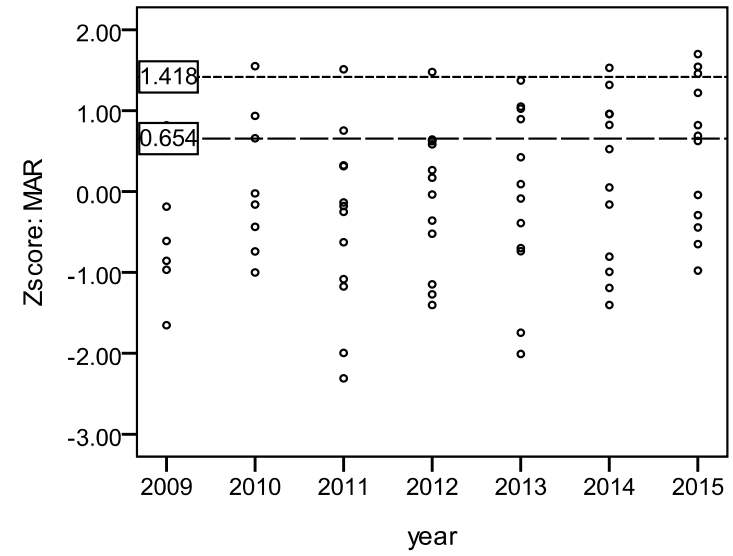

Figure 4. Scatter diagram of standardized values of original data and threshold values. Panel a is the threshold values of science-based cooperation (SCI) and Panel b is threshold values of market-based cooperation (MAR)..

The results of the models also show that SCAL has a positive effect on internal R\&D, cooperative $R \& D$ and market performance, while it has a negative effect on $R \& D$ reserve performance. Enterprise scale measures enterprise resource endowment, which can reflect the uncertainty of enterprise management and the ability to support R\&D activities [52]. Previous studies have shown that there was a positive correlation between firm size and R\&D performance because of the R\&D scale economy of large companies [53]. In reality, although China's textile industry has benefited from scale economy in recent years, enterprises have carried out many activities focusing on application research at the same time. Scale economy has brought about a significant increase in market performance. The large-scale enterprises in China's textile industry still have the problems of insufficient R\&D investment and low innovation ability, which greatly limit the increase of patent output in the industry. On the other hand, in the context of economic transformation, small-scale enterprises actively carry out R\&D activities to improve their competitiveness. They are committed to the accumulation of R\&D capacity under the role of government funding. The improvement of research reserve performance has been brought about. Therefore, there is a negative effect of enterprise scale on research reserve performance.

It is difficult to summarize the law of regression coefficients of YEAR. Perhaps the absolute amount of government funding and R\&D investment may be different during the two periods. However, there is no obvious trend in their effect on innovation performance over time.

\section{Conclusions and Discussion}

\subsection{Conclusions}

This paper integrated government funding, internal R\&D, science-based cooperation, market-based cooperation and innovation performance into one framework, systematically exploring the direct and indirect effects of government funding on innovation performance of the Chinese textile industry. The main conclusions are:

(1) Government funding has a significant direct promoting effect on the internal R\&D and science-based cooperation of enterprises, but has no significant direct promoting effect on 
market-based cooperation. Government funding indirectly promotes market-based cooperation through internal R\&D.

The positive correlation between government funding and internal R\&D confirms the previous research results that government support can stimulate internal R\&D [43,54]. Beck et al. (2016) also studied the impact and effectiveness of government funding policies. He believed that R\&D investment guided by government funded policies was significant for the radical innovation of enterprises [9].

Government funding has a direct promoting effect on science-based cooperation, but has no direct effect on market-based cooperation. Government funding has an indirect effect on market-based cooperation through internal R\&D. This is similar to the research of Cano-Kollmann (2016) [2] and Kang and Park (2012) [42]. Using data from more than 5000 companies in European countries, Cano-Kollmann (2016) found that innovation support policies can increase the openness of enterprises. Kang and Park (2012) found that the impact of government support on upstream linkages (cooperation between enterprises and university scientific research institutions) was more than four times that on downstream linkages (cooperation between enterprises and other institutions). His view was also that the government aims to strengthen the cooperation mechanism between universities and industry through R\&D project funding. The results showed the effectiveness of the funding policy on SCI.

Under the special background of the new normal of China's economy, government funding tends to choose social welfare projects and has more decision-making power on these projects in order to correct market failure. These innovative projects have the characteristics of complexity and spillover, so that the enterprises carrying out such projects get less revenue than they expected. In addition, due to the limitation of R\&D capability, enterprises will not actively carry out R\&D activities related to these projects. This is because universities and scientific research institutions have a large number of frontier knowledge and technology which can be absorbed, utilized and transformed by enterprises. Government supplements scarce resources for enterprises and encourages enterprises to cooperate with universities and scientific research institutions, so as to achieve the consistency of enterprise purpose and government purpose. Therefore, government funding has a significant promotion effect on science-based cooperative projects.

Market-based cooperation is the result of enterprises participation in market competition. Enterprises rely on their own capabilities to search for partners and cooperation projects. Enterprises have more decision-making power on such R\&D projects. In order to maximize profits, enterprises will choose projects with short development cycles and high rates of return. Enterprises can quickly acquire complementary resources from partners by purchasing or introducing them. Market-based cooperation can't effectively correct market failures, so its purpose is inconsistent with that of the government. Therefore, the direct promoting effect of government funding on market-based cooperation is not significant. Internal R\&D plays an intermediary role between government funding and cooperative R\&D. De Jong and Freel (2010) believe that internal R\&D helps enterprises find partners with high professional knowledge [55].Internal R\&D efforts have a positive impact on external cooperation [42].

(2) Both internal R\&D and market-based cooperation have significant promoting effects on innovation performance. Science-based cooperation has significant promoting effects only on research reserve performance. Among them, internal R\&D has the greatest promoting effect, followed by science-based cooperation. Market-based cooperation has the least promoting effect. The promoting effects of internal R\&D and cooperative $R \& D$ on $R \& D$ reserve performance are greater than those on market performance.

The government has probably made some achievement in supporting textile enterprises to carry out scientific cooperation and thus improve innovation performance. Presently, government funds may not be limited to providing funds, but try to optimize the university-enterprise cooperation environment, strengthen the exchange and cooperation between enterprises, and then promote the spillover effect of innovation resources. To a certain extent, these changes may have reversed the situation where enterprises were blindly pursuing the maximization of short-term market interests in low-level cooperation. Jugend et al. (2018) took enterprises in Brazil as objects and got similar 
conclusions. They found that when considering the government's support, the external cooperation of enterprises has a positive impact on innovation performance [56].

Science-based cooperation has significant promoting effects on research reserve performance. Research showed that the cooperation between enterprises and universities or scientific research institutions involves the transfer of tacit and complex knowledge which can be used in the general business processes of enterprises and help to improve research reserve performance [42]. Sz ü CS et al. evaluated the impact of the EC's Seventh Framework Project and found that the number of participants, especially the number of university participants, had a positive impact on performance [57].

The impact of cooperative $R \& D$ on research reserve performance is greater than that on market performance. Based on the influence of government funding, the cooperative R\&D of enterprises has greatly promoted $R \& D$ reserve performance, but failed to bring a greater promoting effect on market performance. Firstly, government funding has a direct promoting effect on science-based cooperation. In the case of limited R\&D resources, enterprises will make full use of the advantages of government policies and focus on scientific cooperation and basic research. The impact of cooperative R\&D on market performance is not obvious in short term. Technological innovation will inevitably lead to the change of production function. Generally, the motivation of technological innovation is profit. Although there may be "innovation does not make money" in the short term, the market performance of enterprises is expected to be improved in the long term. The conclusions of this paper are based on a limited period of time, reflecting the short-term effect of government funding and cooperative $R \& D$. Secondly, the existing R\&D achievements are research-oriented-focusing on basic research and aiming at knowledge output rather than market share. The lack of market orientation in innovation activities leads to a disconnection between scientific research achievements and the market. So, the performance of R\&D innovation mostly stays at the stage of scientific research achievements and has not been translated into real productivity effectively.

(3) Government funding has no direct effect on innovation performance, but has indirect effects on it. The indirect effects are mainly as follows: firstly, government funding promotes internal R\&D, and then internal R\&D promotes innovation performance; secondly, government funding promotes internal $R \& D$, internal $R \& D$ promotes cooperative $R \& D$, and then cooperative $R \& D$ promotes innovation performance; thirdly, government funding promotes science-based cooperation, and then science-based cooperation promotes innovation performance. The results are slightly different from previous studies. Kang et al. (2012) believed that the government had a direct and indirect impact on the innovation output by stimulating the internal $R \& D$ activities of enterprises and domestic cooperation [43]. Beck et al. (2016) believed that the internal R\&D guided by government funded policies was significant for radical innovation, while cooperative R\&D did not enhance the policy effect [9].

As the main body of innovation, the textile enterprise has many external knowledge sources to choose from. For the sake of low cost and low risk, enterprises choose to purchase or acquire technology from outside. Moreover, due to the weak absorptive capacity of enterprises, the knowledge provided by partners has not been truly absorbed and digested by enterprises. Therefore, as shown in the path graph in Figure 2, it is difficult for government funding to give full play to its effectiveness in promoting enterprise innovation performance.

(4) Cooperative R\&D has a threshold effect in the process of government funding affecting innovation performance. The threshold value of cooperative R\&D in the progress of government funding affecting market performance is lower than those in the progress of government funding affecting $R \& D$ reserve performance. When the cooperative R\&D intensity of enterprises can't break through the threshold value, the positive promotion effect of government funding will not be brought into play.

In the stage of low-intensity cooperative $R \& D$, the interaction between enterprises and partners is insufficient. With a lack of close innovation behavior cooperation, enterprises will tend to use external resources directly for simple market innovation; such as through signing a short-term technology sales contract to obtain more mature technology and services, and then improve market performance. 
Although low-level cooperation can improve market performance rapidly, it cannot promote research reserve performance due to the lag of research reserve performance. Therefore, government funds generally indirectly promote market performance. In the stage of high-intensity cooperative $R \& D$, partners achieve the integration of R\&D models through joint research or joint development. After digesting and absorbing the external resources, enterprises have more capital for R\&D reserve innovation. Government funding can promote deep interactions between participants, encourage universities and scientific research institutions to spread breakthrough technology to enterprises, and promote the deep cooperation between RD personnel of enterprises and public scientific research institutions. The internal technological capability structure of enterprises can be upgraded and optimized [58].Therefore, the results of high-intensity cooperation funded by the government are different from those of low-intensity cooperation, which greatly increases the opportunities for enterprises to achieve independent innovation, thus improving the performance of the research reserve. Therefore, the threshold value of cooperative $R \& D$ is high in the process of government funding promoting R\&D reserve performance.

\subsection{Managerial Implications}

(1) In the process of building a national innovation system, the role of government funding is crucial. Presently, the leverage effect of government financing on the innovation performance of the textile industry does not seem to be brought into full play. Therefore, it is necessary to build a clear transmission mechanism of government funding purpose. Due to the unclear transmission mechanism, the purpose of government funding deviates from the result of funding behavior. The internal R\&D of enterprises plays an important role in the whole innovation system. The promoting effect of government funding on internal R\&D is the key to the whole innovation chain. The government should clarify the target of subsidization more clearly and motivate enterprises to actively carry out internal $R \& D$. Enterprises should be encouraged to cooperate with other institutions in the R\&D stage and compete in the downstream output stage. Regarding the object, government should focus on funding enterprises which have similar innovative purposes and corresponding resources and capabilities. Therefore, the positive effect of government funding on innovation performance can be promoted through purpose synergy.

(2) The effect of market-based cooperation on innovation performance is less than that of science-based cooperation. Market-based cooperation may have not fully played its role in promoting innovation performance which is contrary to the original intention of government. It may be necessary to establish an open innovation platform driven by the government. The goal of the innovation platform should be consistent with that of enterprise independent innovation. At the same time, the cooperative $R \& D$ dynamic assessment and supervision mechanism of innovation platform also needs to be established. With the help of this platform, the purpose of government funding can be transmitted through a high-intensity R\&D cooperation mechanism, so as to truly promote the sharing of front-edge technology and collaborative innovation among partners in the platform.

(3) There may be a lack of market-oriented innovation in China's textile industry. It leads to the disconnection between $R \& D$ achievements and the market demand, and eventually leads to the obstruction of the channel for achievements transformation. The government should formulate targeted measures to improve the conversion rate of R\&D achievements. In the process of participating in cooperation, enterprises should be guided to overcome market inefficiency related to technological innovation as far as possible. Enterprises should be encouraged to adhere to the market orientation of R\&D achievements, so as to improve the speed of the commercialization of new products.

\subsection{Limitations and Future Research}

The small sample size is a major limitation of this study. Therefore, the universality of the conclusions still needs to be tested. Future researches can start from the micro level—obtaining a large quantity of first-hand data through the survey of enterprises, in order to improve the robustness and 
universality of conclusions. In addition, we have added the R\&D model between the input side and the output side of the innovation process in this study. Future studies on the effect of government funding can also consider the moderating effect of funding forms, partners, macro-environment and other factors which would help explain the relationship between government funding and innovation performance more comprehensively.

Author Contributions: Conceptualization, Z.Z. and H.C.; methodology, Z.Z. and H.C.; software, Z.Z.; validation, Z.Z. and Y.Y.; formal analysis, Z.Z.; investigation, Z.Z. and Y.Y.; resources, Z.Z. and Y.Y.; data curation, Z.Z.; writing-original draft preparation, Z.Z.; writing-review and editing, H.C. and Y.Y.; visualization, Z.Z.; supervision, H.C.; project administration, H.C.; funding acquisition, H.C. All authors have read and agreed to the published version of the manuscript.

Funding: This research was funded by The Funding of National Natural Science Foundation of China, grant number 71473228. Philosophy and Social Science Planning Project of Hangzhou, Zhejiang, China, grant number Z19JC055. Philosophy and Social Science Planning Project of Hangzhou, Zhejiang, China, grant number Z19JC046. Key Research Institute of Philosophy and Social Sciences for Ecological Civilization Research Center Project of Zhejiang Province, China, grant number 16STYB05. The Funding of National Natural Science Foundation of China, grant number 11701518.

Acknowledgments: The authors acknowledge all those who participated in innovation management team of Zhejiang Sci-Tech University. A special thanks to the electronic information department for their technical support.

Conflicts of Interest: The authors declare no conflict of interest.

\section{References}

1. Love, J.H.; Roper, S. Internal Versus External R\&D: A Study of R\&D Choice with Sample Selection. Int. J. Econ. Bus. 2002, 9, 239-255.

2. Cano-kollmann, M.; Hamilton, R.D.; Mudambi, R. Public support for innovation and the openness of firms' innovation activities. Ind. Corp. Chang. 2016, 26, 421-442. [CrossRef]

3. Dimos, C.; Pugh, G. The effectiveness of R\&D subsidies: A meta-regression analysis of the evaluation literature. Res. Policy 2016, 45, 797-815.

4. Fernández-Sastre, J.; Montalvo-Quizhpi, F. The effect of developing countries' innovation policies on firms' decisions to invest in R\&D. Technol. Forecast. Soc. Chang. 2019, 143, 214-223.

5. Veugelers, R. Internal R\&D expenditures and external technology sourcing. Res. Policy 1997, 26, $303-315$.

6. Krzeminska, A.; Eckert, C. Complementarity of internal and external R\&D: Is there a difference between product versus process innovations. RD Manag. 2016, 46, 931-944.

7. Laursen, K.; Salter, A. Open for innovation: The role of openness in explaining innovation performance among U.K. manufacturing firms. Strateg. Manag. J. 2006, 27, 131-150. [CrossRef]

8. Marino, M.; Lhuillery, S.; Parrotta, P.; Sala, D. Additionality or crowding-out? An overall evaluation of public R\&D subsidy on private R\&D expenditure. Res. Policy 2016, 45, 1715-1730.

9. Beck, M.; Lopes-Bento, C.; Schenker-Wicki, A. Radical or incremental: Where does R\&D policy hit? Res. Policy 2016, 45, 869-883.

10. Bogers, M.; Afuah, A.; Bastian, B. Users as Innovators: A Review, critique, and future research directions. Soc. Sci. Electron. Publ. 2009, 36, 857-875. [CrossRef]

11. Gesing, J.; Antons, D.; Piening, E.P.P.; Rese, M.; Gesing, J.; Antons, D.; Piening, E.P. Joining Forces or Going It Alone? On the Interplay among External Collaboration Partner Types, Interfirm Governance Modes, and Internal R\&D. J. Prod. Innov. Manag. 2015, 32, 424-440.

12. Spanjol, J.; Qualls, W.J.; Rosa, J.A. How many and what kind?The role of strategic orientation in new product ideation. J. Prod. Innov. Manag. 2011, 28, 236-250. [CrossRef]

13. Amit, R.; Schoemaker, P.J.H. Strategic assets and organizational rent. Strateg. Manag. J. 1993, 14, 33-46. [CrossRef]

14. Hussinger, K. R\&D and subsidies at the firm level: An application of parametric and semiparametric two-step selection models. J. Appl. Econ. 2008, 23, 729-747.

15. Czarnitzki, D.; Hottenrot, H. Financing Constraints for Industrial Innovation: What do We Know? Rev. Bus. Econ. Lit. 2010, 55, 346-363. [CrossRef]

16. Feldman, M.P.; Kelley, M.R. The ex ante assessment of knowledge spillovers: Government R\&D policy, economic incentives and private firm behavior. Res. Policy 2006, 35, 1509-1521. 
17. Kleer, R. Government R\&D subsidies as a signal for private investors. Res. Policy 2010, 39, 1361-1374.

18. David, P.A.; Hall, B.H.; Toole, A.A. Is public R\&D a complement or substitute for private R\&D? A review of the econometric evidence. Res. Policy 2000, 29, 497-529.

19. Lee, C. The differential effects of public R\&D support on firm R\&D: Theory and evidence from multi-country data. Technovation 2011, 31, 256-269.

20. Mayer, H. Catching Up: The Role of State Science and Technology Policy in Open Innovation. Econ. Dev. Q. 2010, 24, 195-209. [CrossRef]

21. Hoffmann, W.H.; Schlosser, R. Success Factors of Strategic Alliances in Small and Medium-Sized Enterprises-An Empirical Survey. Long Range Plan. 2001, 34, 357-381. [CrossRef]

22. Maietta, O.W. Determinants of university-firm R\&D collaboration and its impact on innovation: A perspective from a low-tech industry. Res. Policy 2015, 44, 1341-1359.

23. Marzucchi, A.; Antonioli, D.; Montresor, S. Industry-research co-operation within and across regional boundaries. What does innovation policy add? Pap. Reg. Sci. 2015, 94, 499-524. [CrossRef]

24. Cheng, H.; Zhang, Z.; Huang, Q.; Liao, Z. The effect of university-industry collaboration policy on universities' knowledge innovation and achievements transformation: Based on innovation chain. J. Technol. Transf. 2018. [CrossRef]

25. Bayona, C.; García-Marco, T.; Huerta, E. Firms' motivations for cooperative R\&D: An empirical analysis of Spanish firms. Res. Policy 2001, 30, 1289-1307.

26. Cassiman, B.; Pérez-Castrillo, D.; Veugelers, R. Endogenizing know-how flows through the nature of R\&D investments. Int. J. Ind. Organ. 2002, 20, 775-799.

27. De Man, A.; Duysters, G. Collaboration and innovation: A review of the effects of mergers, acquisitions and alliances on innovation. Technovation 2005, 25, 1377-1387. [CrossRef]

28. Hagedoorn, J.; Wang, N. Is there complementarity or substitutability between internal and external R\&D strategies? Res. Policy 2012, 41, 1072-1083.

29. Miotti, L.; Sachwald, F. Co-operative R\&D: Why and with whom? Res. Policy 2003, 32, 1481-1499.

30. Negassi, S. R\&D co-operation and innovation a microeconometric study on French firms. Res. Policy 2004, 33, 365-384.

31. Aschhoff, B.; Sofka, W. Innovation on demand-can public procurement drive market success of innovations? Res. Policy 2009, 38, 1235-1247. [CrossRef]

32. Lee, E.Y.; Cin, B.C. The effect of risk-sharing government subsidy on corporate R\&D investment: Empirical evidence from Korea. Technol. Forecast. Soc. Chang. 2010, 77, 881-890.

33. Flor, M.L.; Cooper, S.Y.; Oltra, M.J. External knowledge search, absorptive capacity and radical innovation in high-technology firms. Eur. Manag. J. 2018, 36, 183-194. [CrossRef]

34. Becheikh, N.; Landry, R.; Amara, N. Lessons from innovation empirical studies in the manufacturing sector: A systematic review of the literature from 1993-2003. Technovation 2009, 26, 644-664. [CrossRef]

35. Cassiman, B.; Veugelers, R. In Search of Complementarity in Innovation Strategy: Internal R\&D and External Knowledge Acquisition. Manag. Sci. 2006, 52, 68-82.

36. Van de Vrande, V.; de Jong, J.P.J.; Vanhaverbeke, W.; de Rochemont, M. Open innovation in SMEs: Trends, motives and management challenges. Technovation 2009, 29, 423-437. [CrossRef]

37. Hannigan, T.J.; Cano-Kollmann, M.; Mudambi, R. Thriving innovation amidst manufacturing decline: The Detroit auto cluster and the resilience of local knowledge production. Ind. Corp. Chang. 2015, 24, 613-634. [CrossRef]

38. Giannopoulou, E.; Barlatier, P.; Pénin, J. Same but different? Research and technology organizations, universities and the innovation activities of firms. Res. Policy 2019, 48, 223-233. [CrossRef]

39. Okamuro, H.; Nishimura, J. Not just financial support? Another role of public subsidy in university-industry research collaborations. Econ. Innov. New Technol. 2016, 24, 633-659. [CrossRef]

40. Tomlinson, P.R. Co-operative ties and innovation: Some new evidence for UK manufacturing. Res. Policy 2010, 36, 762-775. [CrossRef]

41. Holl, A.; Rama, R. Technology sourcing: Are biotechnology firms different? An exploratory study of the Spanish case. Sci. Public Policy 2012, 39, 304-317. [CrossRef]

42. Kang, K.; Park, H. Influence of government R\&D support and inter-firm collaborations on innovation in Korean biotechnology SMEs. Technovation 2012, 32, 68-78. 
43. Granstrand, O.; Patel, P.; Pavitt, K. Multi-technology corporations: Why they have "distributed" rather than "distinctive core" competencies. Calif. Manag. Rev. 1997, 39, 8-25. [CrossRef]

44. Lahiri, N.; Narayanan, S. Vertical integration, innovation, and alliance portfolio size: Implications for firm performance. Strateg. Manag. J. 2013, 34, 1042-1064. [CrossRef]

45. Cordero, R. The measurement of innovation performance in the firm: An overview. Res. Policy 1990, 19, 185-192. [CrossRef]

46. Govindarajan, V.; Kopalle, P.K. Disruptiveness of Innovations: Measurement and an Assessment of Reliability and Validity. Strateg. Manag. J. 2006, 27, 189-199. [CrossRef]

47. Hagedoorn, J.; Cloodt, M. Measuring innovative performance: Is there an advantage in using multiple indicators. Res. Policy 2003, 32, 1365-1379. [CrossRef]

48. Artz, K.W.; Norman, P.M.; Hatfield, D.E.; Cardinal, L.B. A Longitudinal Study of the Impact of R\&D, Patents, and Product Innovation on Firm Performance. J. Prod. Innov. Manag. 2010, 27, 725-740.

49. Baghana, R.; Mohnen, P. Effectiveness of R\&D tax incentives in small and large enterprises in Que'bec. Small Bus. Econ. 2009, 33, 91-107.

50. Preacher, K.J.; Hayes, A.F. Asymptotic and resampling strategies for assessing and comparing indirect effects in multiple mediator models. Behav. Res. Methods 2008, 40, 879-891. [CrossRef]

51. Taylor, A.B.; MacKinnon, D.P.; Tein, J. Tests of the Three-Path Mediated Effect. Organ. Res. Methods 2008, 11, 241-269. [CrossRef]

52. Lee, R.P.; Chen, Q. The Immediate Impact of New Product Introductions on Stock Price: The Role of Firm Resources and Size. J. Prod. Innov. Manag. 2010, 26, 97-107. [CrossRef]

53. Blind, K.; Edler, J.; Frietsch, R.; Schmoch, U. Motives to patent: Empirical evidence from Germany. Res. Policy 2006, 35, 655-672. [CrossRef]

54. Czarnitzki, D.; Licht, G. Additionality of public r\&d grants in a transition economy: The case of eastern germany. Econ. Transit. 2005, 14, 101-131.

55. De Jong, J.P.J.; Freel, M. Absorptive capacity and the reach of collaboration in high technology small firms. Res. Policy 2010, 39, 47-54. [CrossRef]

56. Jugend, D.; Jabbour, C.J.C.; AlvesScaliza, J.A.; Rocha, R.S.; Junior, J.A.G.; Latan, H.; Salgado, M.H. Relationships among open innovation, innovative performance, government support and firm size: Comparing Brazilian firms embracing different levels of radicalism in innovation. Technovation 2018, 74, 54-65. [CrossRef]

57. Szücs, F. Research subsidies, industry-university cooperation and innovation. Res. Policy 2018, 47, $1256-1266$. [CrossRef]

58. Aslesen, H.W.; Isaksen, A. New perspectives of knowledge-intensive services and innovation. Geogr. Ann. 2007, 89, 45-58. [CrossRef]

(C) 2020 by the authors. Licensee MDPI, Basel, Switzerland. This article is an open access article distributed under the terms and conditions of the Creative Commons Attribution (CC BY) license (http://creativecommons.org/licenses/by/4.0/). 